\title{
Tree Transplanting: Success Stories of Trees Transplanting at Karnataka, India
}

\author{
Yashpal Kshirsagar, B. Palanikumaran*, T.V. Manjunatha, \\ Sonal Vrishini and Kiranangadi
}

Karnataka Forest Department, India

*Corresponding author

\section{A B S T R A C T}

\section{Keywords}

Transplanting, Root pruning, Tree lifting

Article Info

Accepted:

20 September 2018

Available Online:

10 October 2018
Tree establishment and success stories of transplanting depends on various sequence of event viz., tree size, type of root system, shoot and root pruning methods, health of the tree, distance of transportation, season of transplanting, soil and local weather condition at both sides, pre and post transplantation care of the tree, long period of observation and risk management. In this article clearly addressed the clinical methodology for tree transplanting and its impact on the society. This article also reviews the treatments for the tree (before and after transplanting), tree lifting and removal methods, transportation and economics for good tree transplanting.

\section{Introduction}

Tree Transplanting is an old practice, which has been employed to rescue, save, or salvage certain trees, which are under threat of cutting or removal or damage due to various reasons.

Such of those trees which are under threat and which also assume importance due to their rarity of occurrence, species type, endangered status, size, age, location, religious importance, medicinal value, emotional value, aesthetic value, etc., can be considered for Transplanting. Again, though the practice is not new, the technique cannot be applied for all species of all ages at all places. It cannot be done on a large scale basis, also (Gilman, Edward, 1997). Hence, this technique can be employed for a small scale, exigent situation and site specific reasons where few trees of immense importance can be tried for Transplanting.

\section{Need for tree transplanting}

There is a need to take up such experiments, acquire field knowledge and prepare package of practices on this Technique so that it can be employed 'as and when' required based on technical suitability. The Forest department is the nodal department for any queries related to Trees and wild animals. Hence, a wellstructured 'Standard Operative Procedure' (SOP) can be developed on Tree Transplanting based on the past experience and the on-going experiments at various forest divisions in the state. 
It is also pertinent to mention that large number of well grown trees are in/face danger of cutting during the implementation of developmental projects like road widening, railway line, water related projects, mining etc., The people, politicians, media, conservationists, environmentalists, judiciary, etc., take cognizance of the fact that the trees are being cut without giving a second thought. They also ask, whether such of these trees can be saved?

Since their concern is genuine, we need to address such concerns by educating them with the technicalities involved in dealing with these live specimens. Under such circumstances, the transplanting technique can be of some help for selected species depending on the factors as detailed above.

A similar exigent situation arose in Gadag Forest division in Dharwad circle where, about 1300 trees were to be cut in the Gadag district for road widening project between Hubballi and Hosapete implemented by NHAI and about 500 trees were to be cut in a Water impounding project. The Gadag District administration showed keen interest and commitment to save as many of these trees from cutting and relocate/transplant them in suitable places. Then the Gadag Forest division got involved and planned for Tree Transplanting, in consultation with the senior officers. The trees were selected, based on the criteria cited above, they were transplanted. The post-transplant care is being taken adequately and these trees are showing the signs of survival and establishment. But, these trees are to be observed for at least for twelve months to ascertain their successful establishment and growth. Various environmental conservation agencies, NGOs, Scientists, press/media, people, politicians etc., have expressed their satisfaction about the methods adopted for transplanting and are confident that these trees will survive.

\section{Methodology adopted}

The entire process of the Tree Transplanting experiment has to be planned as below: (These methods are applicable for One meter and above girth class trees also.

Changes can be adopted as per local conditions and size and girth of the tree).

Various teams should be formed like, Tree treatment team, Transport team, Machine/material procurement team, Logistics team, Liaison team etc., with designated work chart and responsibilities.

Overall works have to be planned, executed and monitored by the Steering team comprising of senior level officers of all the departments involved and should own responsibility for the outcome of the process.

All the trees coming in the zones of developmental works have to be listed and inventoried. Species wise, girth wise, location wise classification should be done.

Various Agricultural scientists (for plant protection measures), NGOs, related Departments, agencies should be contacted to gather information on the subject and the field techniques, procurement of machines, plant care details, etc.

After gathering all the required information, the list of trees suitable for transplanting has to be prepared and the suitable locations should be identified for their transplanting.

The points to be kept in mind are that the tree undergoes several shocks during its removal from the original site, like, Root injury, exposure to Sun, detachment from mother soil, lack of moisture, infection, injury during transport, alien new soil conditions, duration of travel, etc., 
The machines like JCBs, 10 to 20 Tonne capacity Crane, Long vehicle for transport, Lorries, Ropes, Gunny bags, packing materials, Water tankers, etc., have to be procured. Almost all these machines are required in two sets, one at original Tree site (for lifting the tree) and the other at the Receptor/Transplanting site (for inserting into pit and making it stand firm).

Adequate men force at both sites to facilitate smooth handling of the tree while lifting, loading, transport, transplanting, etc.

Support from other departments like, District administration, Health department, Police, Telecom, Electricity, Municipality, Agriculture, etc., is essential.

After procuring all the information about pre $\&$ post care details and identifying the target trees, receptor site, suitable season, etc., the operation can be scheduled for execution.

\section{Treatment to the tree}

General health, size, species, root system etc., of the tree should be assessed before deciding about its removal and transplanting. Only a good and promising tree should be considered. The pre-treatment to the tree should begin at least 5 to 7 days prior to actual removal of tree. One meter deep trench has to be dug around the tree trunk at a distance of about 1.5 to $2.0 \mathrm{M}$ from the tree trunk (as in pic) with a medium bucket JCB and water it continuously. Watering should be done in the trench only. The shape can be either Rectangular or Spherical, as per local convenience. This will help to soften the soil and pre-condition the roots for mild exposure and displacement. Care should be taken to lift larger sized trees with bigger root balls so that more roots are encompassed to ensure better re-growth and early establishment. Root growth promoters can be used (Harris, J, Roger and Nina L. Bassuck, 1993). The Antibacterial and Antifungal spray/solution can be used if any roots are exposed and found injured. Crown pruning or root pruning can be done depending on the species and local conditions. But care should be taken that the injury caused to the tree is minimum.

\section{Treatment at the receptor/transplanting site}

The receptor site should be selected in such a way that it is very close or almost similar to the original site conditions and the treatment should start at least 5 to 7 days prior to transplanting. A $3 \times 3 \times 3 \mathrm{M}$ or $2 \times 2 \times 2 \mathrm{M}$ or any convenient sized pit is to be dug (as in pic) depending on the size (girth $\&$ height) of the tree and its intact root ball that is being transported along with the tree. The thumb rule is, the transplanted tree should have atleast Two feet extra space/radius in the pit, after its placing in the pit which helps the roots to establish in a well-treated, nutrient rich, infection free soil. This pit should be watered daily, proper drainage given and cut surfaces may be drenched with antifungal/antibacterial/anti-termite/dung slurry or solutions. After three days, the pit should be filled to a height of One meter (from bottom of the pit) with adequate good quality organic manure/vermi-compost/FYM and Mother Soil or good local soil. Mother soil is the soil from the original site of the Target tree that is to be transplanted. This will help the transplanted tree to find a comfortable root zone. Then continue watering till last day but care should be taken to keep the soil well drained.

\section{Tree lifting/Removal}

The tree can be marked for its orientation to East and West directions, so that a similar orientation is maintained (as far as possible) at the receptor site also. On the day of 
transplanting, the tree should be adequately padded at its trunk with gunny bags (as in pic) where the Crane will hold and lift from the top. The tree trunk should also be tied with good sized ropes at its trunk to enable it to lodge/lie on to the long vehicle/lorry. The soil has to be loosened further with a JCB and the ball of earth with a big mass of intact roots can be lifted. JCB will assist to free the roots by a little, gentle push from below and the Crane should lift the tree from the top (as in pic).

This will help the tree to free itself with minimum possible damage to roots. When the tree is freed from the soil, the roots and the soil ball should be immediately covered with wet gunny bags (or can be done after placing the tree on the vehicle). Then the tree is lifted up in the air and with the help of ropes, it can be laid to sleeping position (as in pic) with its roots and soil ball facing towards the engine. Smaller trees (less than $70 \mathrm{~cm}$ girth) can be transported in lorries keeping them in vertical position (as in pic).

\section{Tree transporting}

After the tree is loaded on to the vehicle, it should be tied to the vehicle at suitable points to keep it in good hold and position during travel. The roots and the soil ball should be constantly kept covered with wet gunny bags and watered to reduce the impact of exposure to sun and desiccation. The Mother soil from the root zone should be loaded into the vehicle, covering the gaps so that the tree gets the required cushion during travel. This soil can be used for filling into the pit at the transplanting site (as in pic).

The tree branches can be tied, without breaking them, to enable smooth movement. The vehicle should move at such a speed which should not cause any injury to the tree. All the overhead cables/wires/obstacles should be kept free all along the route. The traffic police should facilitate smooth movement of the vehicle. The Health officers and the Ambulance services should be kept at site at all times during the operation to attend any emergency.

\section{Tree insertion into pit}

When the tree arrives at the transplanting site, about another 0.5 meter height of mother soil is put into the pit along with vermi-compost. Now, the $3.0 \mathrm{M}$ deep pit has become $2.0 \mathrm{M}$ deep. Water the pit adequately to keep the soil moist. Make the tree erect with the help of Crane (as in pic) and keep its balance by using the ropes already tied to it. Now, slowly lower the tree into the pit and with the help of the ropes, bring it to the centre of the pit and insert it orienting to its original East -West position. The gunny bags covering the root ball can be removed. There should be at least Two feet space all around the edge of the root ball and the walls of the pit.

\section{Tree transpalnting}

Now, the tree has occupied almost One meter height in the pit leaving only One meter space above its trunk base (Collar). Fill the pit with Mother soil and already stored good soil to a height of about One Meter above the ground level.

Keep watering till good compaction is achieved. Now, there is One meter mother soil below the roots of the tree and another one meter above it. Over and above this, there is another One meter of good soil (above ground level). This will ensure providing proper balance/compaction to the tree.

\section{Post-care}

Watering needs to be done frequently depending on the season, type of soil, drainage and water quality. But, proper drainage has to be ensured and mulching will help a lot. 
Fig.1 Treatment at the receptor/transplanting site

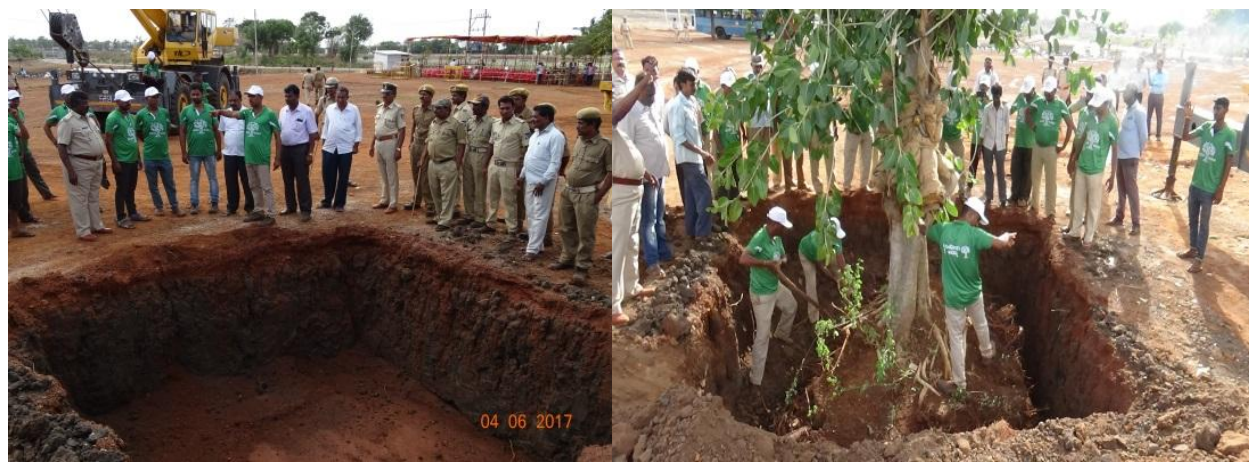

Fig.2 Tree Lifting/Removal

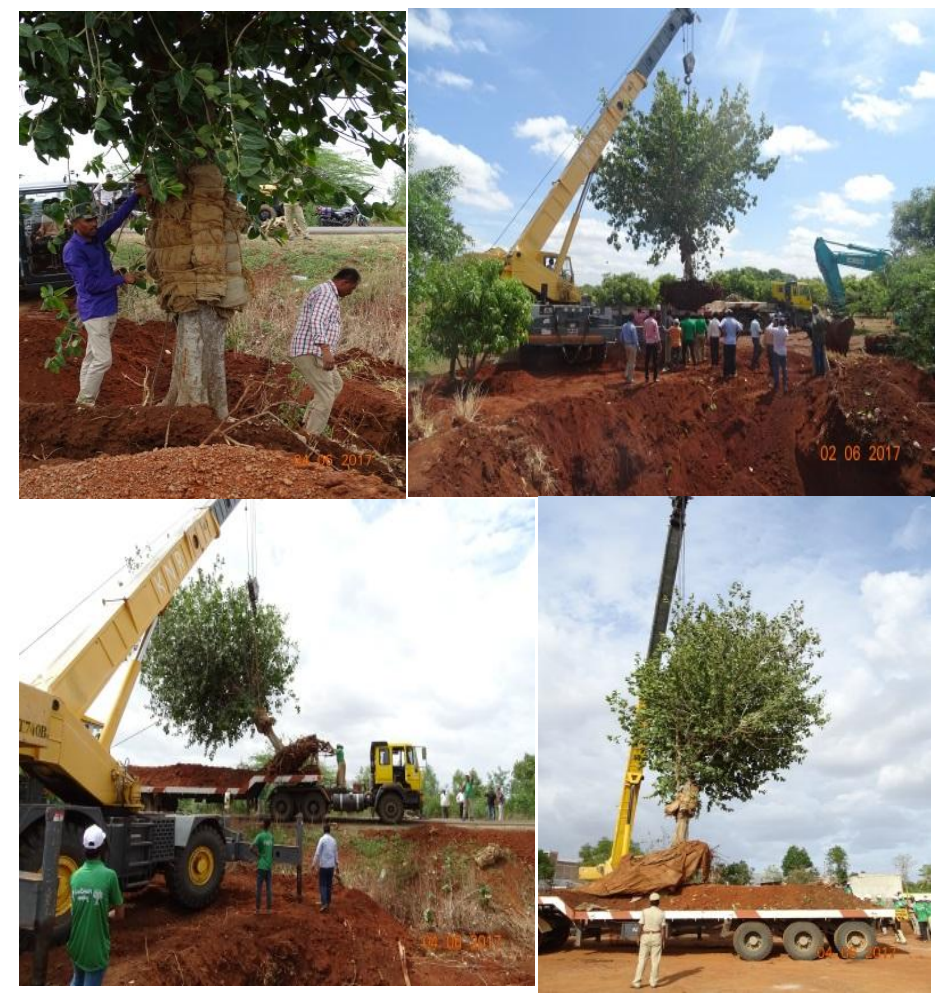

Fig.3 Tree Transporting

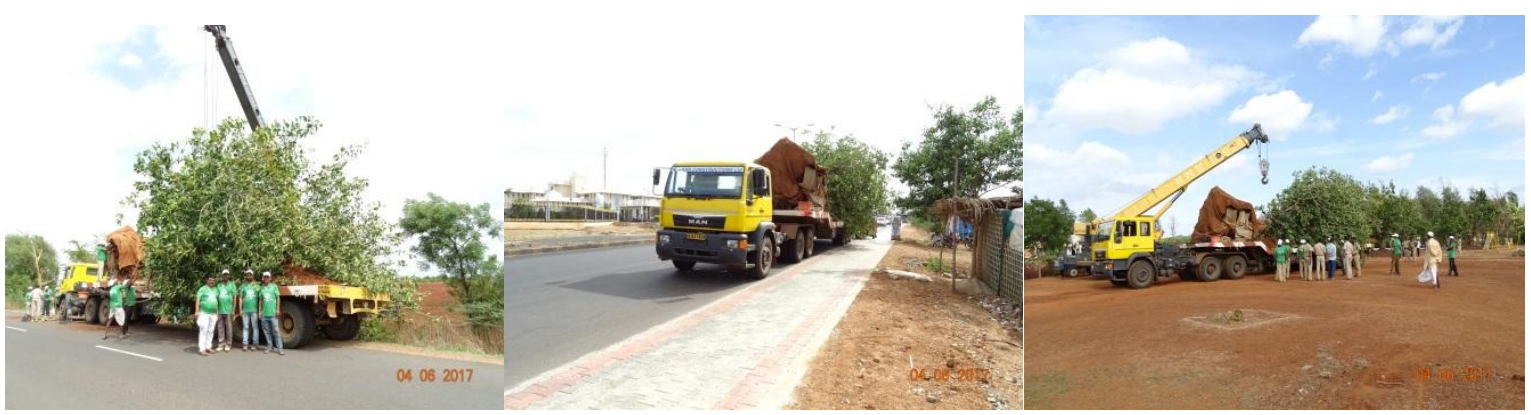


Fig.4 Tree insertion into pit

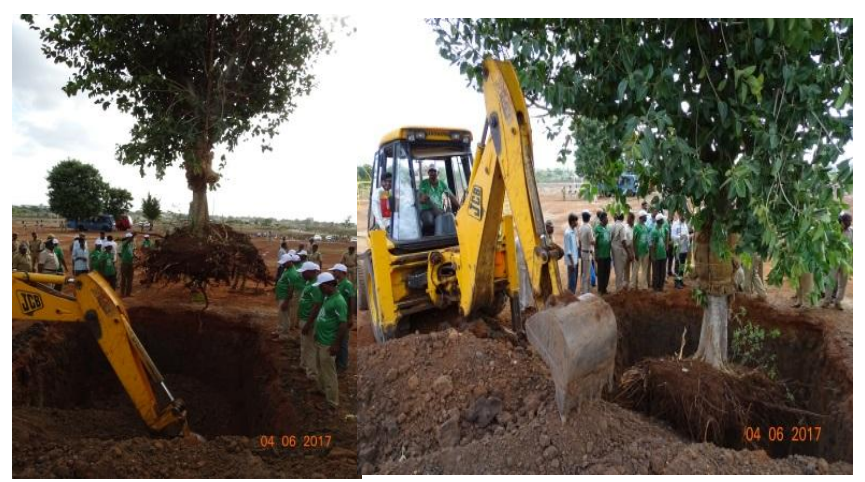

Table.1 Treatment at the receptor/transplanting site

\begin{tabular}{|c|}
\hline NAMIE \\
\hline Anti-termite \\
\hline Antibacterial \\
\hline Antifungal \\
\hline Root hormone \\
\hline Vermi-compost \\
\hline
\end{tabular}

\begin{tabular}{|c|c|c|}
\hline CHEIMICAL & Active Ingredient & QUANTITY per Tree \\
\hline Chlorpyrifos 20\% EC & $4 \mathrm{ml} / 3 \mathrm{~L}$ water & $\mathbf{8 ~ L}$ \\
\hline Bactinash 200 & 17 gms / 3 L & 2 L \\
\hline Corbondazim (Bavistin) & 2 gms / 3 L water & $15 \mathrm{~L}$ \\
\hline IBA & $20 \mathrm{ppm}$ & $\mathbf{2 0} \mathrm{L}$ \\
\hline--- & $15-25 \mathrm{~kg} /$ pit & \\
\hline
\end{tabular}

Table. 2 The details as below

\begin{tabular}{|c|l|c|c|}
\hline & \multicolumn{1}{|c|}{ Species } & No. trees & Survival \% \\
\hline $\mathbf{1}$ & Ficus benghalensis & 281 & 95 \\
\hline $\mathbf{2}$ & Ficus religiosa & 4 & 100 \\
\hline $\mathbf{3}$ & Albizzia lebbek & 6 & 100 \\
\hline $\mathbf{4}$ & Holoptelia integrifolia & 27 & 85 \\
\hline $\mathbf{5}$ & Acacia ferruginea & 6 & 100 \\
\hline $\mathbf{6}$ & Acacia nilotica & 2 & 50 \\
\hline $\mathbf{7}$ & Dalbergia sissoo & 1 & 100 \\
\hline $\mathbf{8}$ & Samania saman & 2 & 100 \\
\hline $\mathbf{9}$ & Ficusinfectoria or virens & 6 & 85 \\
\hline $\mathbf{1 0}$ & Cordiamixa & 1 & 100 \\
\hline $\mathbf{1 1}$ & Azadirachta indica & 1 & 00 \\
\hline $\mathbf{1 2}$ & Aegle marmelos & 1 & 00 \\
\hline $\mathbf{1 3}$ & Zizyphussp & 2 & 00 \\
\hline $\mathbf{1 4}$ & Eucalyptus sp & 17 & 00 \\
\hline
\end{tabular}

** All the trees listed above belong to girth class below $70 \mathrm{~cm}$, except four Ficus benghalensis and one Ficus religiosa which were 1.0 to $1.5 \mathrm{~m}$ in girth. All the five big trees are doing well.

Plant protection measures can be taken depending on the pest/disease, in consultation with the Plant scientists. Growth regulators can be used if necessary. Mild pruning of those branches which are injured or damaged during transport, may be done, to avoid further infection. Apply dung paste or neem paste to the abrasions or injured portions of the trunk or branches. Water spray can be given if the weather is very harsh. Fertilizers and nutritional supplements can be given to enhance its establishment (Appleton, Bonnie and Susan French, 1995).

\section{Observations and Monitoring}

The transplanted tree needs to be observed on a 
daily basis for its survival, growth, pests, diseases and other physiological symptoms/ expressions. It is possible to witness temporary wilting of leaves for few days, leaf fall also can happen and the tree may even decide to go in for 'Transitory Dormancy' phase, to avoid moisture loss and desiccation. But can show revival symptoms within weeks like, new sprouts, turgid leaves, arrest of leaf fall, etc., It is also possible that sometimes, there will be a 'Distress' reaction in the form of premature flowering and fruiting. Also, some trees will exhibit new sprouts within few weeks which may be due to the presence of adequate stored food reserves. Under such circumstances, the new sprouts will not survive for a long and may wither soon. If the tree has not acclimatized, then there will not be any revival symptoms.

It should be kept in mind that the transplanted tree has to withstand the tests of atleast one year (covering all the three seasons) to declare it as 'surviving or successful'. Hence, any premature conclusions and certifications should be restrained. The monitoring team should consist of officers from Forest dept, Agriculture dept, Horticulture dept, Research institutions, etc.

\section{Cost involved}

The cost of transplanting a tree depends on many factors like,

Species and size of the tree

Number of days required for Pre \& Post treatment.

Type and number of machines, material and the man power required

Number of trees to be transplanted per day

Distance of travel and transplant

Plant healthcare materials

Other logistical requirements

As per the expenditure details and the field experience that is witnessed, it is estimated that about Rs.10,000 to Rs.12,000 per tree is required as per the existing Government approved rates for various activities. The cost will vary depending on local conditions.

\section{Species found suitable for transplanting}

As per the experience of the Forest department which has transplanted about 460 trees from May to August, 2017 involving 14 species, some tree species have responded promisingly and some have not.

Other species which are promising as per the experimenta done in other states, are Delonex regia, Tabubiaspp, Butea monosperma, Bombaxsp, Tectona grandis, Psidium guajava, Peltoforum spp, Dalbergia sissoo, Sapindus spp, Nyctanthus arbortristis, Terminalia arjuna, Moringa oleifera, Tecomella undulata, Pongamia pinnata, Justicia adhathoda, Cassia fistula, etc.

\section{Thumb rules for tree transplanting}

It should be kept in mind that Tree Transplanting is not a Routine process and cannot be done in all situations. It should be employed only under exigent and compelling situations to rescue or save a few numbers of trees, which are under threat of removal prematurely.

Species selection is of prime importance. Ficus spp is doing well and the Neem is not at all suitable. Almost all those species which regenerate easily by vegetative propagation, are promising and survive well. Those species with high dependence on tap roots will not be suitable but those with fibrous/lateral roots tend to do well.

The trees with lesser girth, say less than $70 \mathrm{~cm}$, will survive better and are easy to handle and transport.

The Receptor pit size can be $2 \times 2 \times 2 \mathrm{M}$ for all the trees which are less than $70 \mathrm{~cm}$ in girth and for bigger trees the pits can be $3 \times 3 \times 3 \mathrm{M}$ depending on the Root ball size. More the Root ball, more is the advantage for tree to survive. 
There has to be more similarities between Parent site and Receptor site, with respect to soil characteristics and weather conditions.

Rainy season is a better period to take up such transplanting operations which will reduce physiological stresses.

The distance between the Parent site and the Receptor site should be as much less as possible. The Crane should be of atleast 10 tonne capacity for lifting trees of less than 70 $\mathrm{cm}$ girth class.

The pretreatment trench should be one meter deep and 1.5 to 2.0 meter radius from the tree base. Watering to be done in the trench and not to the tree base/root ball earth.

The duration of exposure of roots to Sun should be minimum. There has to be a dedicated team of people at both the sites and the monitoring work should be done on a daily basis.

It should always be kept in mind that Tree is a 'living system'. The success of Tree Transplanting depends on various factors, some beyond our understanding. Hence, the technique has to be seen as one of the possible solutions to save a tree for obvious importance.

\section{Legal regulation}

There has to be a legal support to tree transplanting activities since it involves risks, requires funds, live species of conservation importance, etc. Hence, in order to avoid misuse of this technique, a regulatory mechanism supported by suitable legal provisions is necessary. The Forest department can include suitable sections in Tree Preservation Act or other any suitable Act and make provisions for tree transplanting. There has to be a chapter written in the divisions Working Plans about such techniques and provisions.

The local Circle Chief Conservators of Forests can be authorized to grant permissions to any person (s) or agencies, Government or otherwise, to take up tree transplanting, under the supervision of the Forest department. A committee headed by the Chief Conservators of Forests, involving respective Deputy Conservator of Forests, Agriculture Officers, Horticulture officers, Pathologists, physiologists, NGO, Police, Revenue officers, etc, can be authorized to take decisions about granting such permissions.

These studies recommend that treatment for tree before and after transplanting, tree lifting procedure and transportation from one place to another place. Perhaps legal clearance from government departments and modern equipment's and machines used for successful tree transplanting. Finally, transplant success and establishment in the landscape is dependent on a chain of events from propagation, to maintenance on the job site, to transplanting techniques, to aftercare.

\section{Reference}

Appleton, Bonnie L. and Susan French. 1995. Tree and shrub planting guidelines. Publication 430-295. Virginia Cooperative Extension, Virginia Tech University, Blacksburg, VA.

Gilman, Edward F. 1997. Trees for Urban and Suburban Landscapes. Delmar Publishers, Albany, New York.

Harris, J, Roger and Nina L. Bassuck. 1993. Tree planting fundamentals. Journal of Arboriculture 19(2): 64-70.

\section{How to cite this article:}

Yashpal Kshirsagar, B. Palanikumaran, T.V. Manjunatha, Sonal Vrishini and Kiranangadi. 2018. Tree Transplanting: Success Stories of Trees Transplanting at Karnataka, India. Int.J.Curr.Microbiol.App.Sci. 7(10): 2709-2716. doi: https://doi.org/10.20546/ijcmas.2018.710.315 